\title{
Иерархия общества раннего железного века Западного Казахстана по материалам комплекса Жайык (VI-IV вв. до н.э.)
}

\author{
(C) 2021 г. Лукпанова Я.А.
}

Keywords: archaeology, Zhaiyk, kurgan, burial, Sarmatians, ritual, rite, social status, marker

Түйін сөздер: археология, Жайық, оба, жерлеу, сарматтар, ырым, рәсім, әлеуметтік жағдай, маркер

Ключевые слова: археология, Жайык, курган, погребение, сарматы, ритуал, обряд, социальное положение, маркер

\section{Yana Lukpanova ${ }^{1}$ \\ ${ }^{1}$ Senior researcher, West Kazakhstan Museum of History and Local Lore, Uralsk, Kazakhstan. Email: Lukpanovayana@gmail.com}

\section{Hierarchy of the Early Iron age society of Western Kazakhstan on the materials of the Zhaiyk complex $\left(6^{\text {th }}-4^{\text {th }}\right.$ centuries BC)}

\begin{abstract}
This article is devoted to the study of male burials from mound no. 1 of the Zhaiyk-1 burial ground, which was studied in the field season of 2019. Excavations were planned in connection with the design of the opening of the Zhaiyk Settlement complex. The burial mound Zhaiyk-1 consisted of three earth mounds and was located on the necropolis of the settlement Zhaiyk. Mound no. 1 was destroyed by heavy machinery, gates were built on the periphery of mound no. 2, mound no. 3 was covered with garbage. As a result of archaeological research, 14 burials were studied in mound no. 1, surrounded by a circular moat with a marked entrance on the south side. To the west of the central grave women were buried - five complexes, and men on the east side - eight in total, two in the central burial. Fifteen individuals who were buried in pits located in a semicircle around the central pit, the main part of them is oriented with their heads to the south, southwest, southeast. The resulting material is of different times, deposited over several centuries from the $5^{\text {th }}-4^{\text {th }}$ to the $4^{\text {th }}-3^{\text {rd }}$ centuries BC. Men's burials, unlike women's burials with a small kit, three burials out of eight belong to soldiers, one burial to a child. Their status was higher than other male burials in the mound. One individual is buried belly down; the skeleton of another adult is buried at the bottom of the moat, decapitated. The results of the study of mound no. 1 showed the perspective of the study of this monument, revealed a number of questions on the archaeology of the early nomads of the Iron Age, highlighting the problems of social organization, the hierarchy of society.
\end{abstract}

Citation: Lukpanova Ya. Hierarchy of the Early Iron age society of Western Kazakhstan on the materials of the Zhaiyk complex ( $6^{\text {th }}-4^{\text {th }}$ centuries BC). Kazakhstan Archeology. 2021, 4 (14), 9-26 (in Russian). DOI: 10.52967/akz2021.4.14.9.26

\section{Лұқпанова Яна Амангелдіқызы ${ }^{1}$}

${ }^{1}$ аға ғылыми қызметкер, Батыс Қазақстан облысы тарихи-өлкетану музейі, Орал, Қазақстан. Email: Lukpanovayana@gmail.com 


\title{
Жайық кешені материалдары бойынша Батыс Қазақстан ерте темір дәуірі қоғамының иерархиясы (б.д.д. VI-IV ғғ.)
}

\begin{abstract}
Аннотация. Бұл мақала 2019 ж. далалық маусымда зерттелген Жайық-1 қорымының № 1-обасындағы ер адамдар жерлеуін зерттеуге арналған. Қазба жұмыстары «Жайық бекінісі» кешенін ашу жобасына байланысты жоспарланған. Жайық-1 обасы үш топырақ үйіндіден тұрды және Жайық қонысының қорымында орналасқан. № 1-оба ауыр техниканың күшімен қираған, № 2-обаның шетіне қақпа тұрғызылған, ал № 3-обанның бетін қоқыс басып қалған. Кіреберісі оңтүстік жағында белгіленген сақиналы арықпен қоршалған № 1-обадағы археологиялық зерттеулер нәтижесінде 14 қорым зерттелді. Орталық қорымнан батысқа қарай әйелдер - бес кешен, шығыс жағында сегіз, орталық қорымда - екі ер адам жерленген. Жартылай шеңбер түрінде орналасқан орталық шұңқырдың айналасында шұңқырларға жалпы саны 15 адам жерленген, олардың негізгі бөлігінің бастары О, ОБ, ОШ-қа бағыттаған. Алынған материалдар б.д.д. V-IV ғғ. бастап IV-III ғасырларға дейін бірнеше ғасырлар бойы жинақталған әр түрлі кезеңге жатады. Ерлер жерлеуінің әйелдер қорымдарынан айырмашылығы алынған заттар қарапайым, сегіз жерлеудің үшеуі сарбаздарға тиесілі, біреуінде бала жерленген. Олардың мәртебесі обадағы басқа ерлер қорымдарына қарағанда жоғары болды. Бір адам ішімен төмен қаратылып, екінші бір ересек адамның қаңқасы арық түбіне көміліп, басы кесілген. № 1-обаны зерттеу нәтижелері осы ескерткішті зерттеудің қажеттілігін, темір дәуіріндегі ерте көшпенділердің археологиясы бойынша бірқатар мәселелерді анықтап, әлеуметтік ұйым, қоғам иерархиясы мәселелерін бөліп көрсетті.
\end{abstract}

Сілтеме жасау үшін: Лукпанова Я.А. Жайық кешені материалдары бойынша Батыс Қазақстан ерте темір дәуірі қоғамының иерархиясы (б.д.д. VI-IV ғ.ғ.). Қазақстан археологиясы. 2021. № 4 (14). 9-26-бб. (Орысша). DOI: 10.52967/akz2021.4.14.9.26

\section{Лукпанова Яна Амангелдиевна ${ }^{1}$}

${ }^{1}$ старший научный сотрудник, Западно-Казахстанский областной историкокраеведческий музей, г. Уральск, Казахстан. Email: Lukpanovayana@gmail.com

Аннотация. Статья посвящена исследованию мужских захоронений из кургана № 1 могильника Жайык-1, исследованного в полевом сезоне 2019 г. Раскопки были запланированы в связи с проектированием комплекса «Городище Жайык». Курганная группа Жайык-1 состояла из трех земляных насыпей и была расположена на некрополе городища Жайык. Курган № 1 был разрушен тяжелой техникой, на периферии кургана № 2 сооружены ворота, курган № 3 - засыпан мусором. В результате археологических исследований в кургане № 1, окруженном кольцевым рвом с обозначенным входом с южной стороны, было изучено 14 погребений. К западу от центральной могилы были погребены женщины - пять комплексов, с восточной стороны мужчины восемь, два в центральном погребении. Всего 15 индивидов, которые были погребены в ямах, расположенных полукольцом вокруг центральной ямы, основная их часть ориентирована головой на Ю, ЮЗ, ЮВ Полученный материал разновременный, отложившийся на протяжении нескольких веков от V-IV до IV-III вв. до н.э. Мужские захоронения в отличие от женских со скромным вещевым набором, три погребения из восьми принадлежат воинам, одно погребение ребенку. Их статус был выше по отношению к другим мужским захоронениям в кургане. Один индивид захоронен вниз животом, скелет другого взрослого человека погребен на дне рва и обезглавлен. Результаты исследования кургана № 1 показали перспективность исследования данного памятника, выявили ряд вопросов по археологии ранних кочевников эпохи железа, выделяя проблемы социальной организации, иерархии общества.

Для цитирования: Лукпанова Я.А. Иерархия общества раннего железного века Западного Казахстана по материалам комплекса Жайык (VI-IV вв. до н.э.). Археология Казахстана. 2021. № 4 (14). C. 9-26. DOI: 10.52967/akz2021.4.14.9.26 


\section{Введение}

Могильник Жайык-1 расположен в 13,0 км юго-западнее центральной части города Уральск (ЗападноКазахстанская обл.), на территории некрополя городища Жайык (рис. 1). Он состоит из четырех курганных насыпей. В полевом сезоне 2019 г. был исследован курган № 1, самый большой в курганной группе Жайык-1, аварийный. В начале 2000-х гг. на нем была произведена попытка рекультивации насыпи, в результате чего центральная часть его была снесена тяжелой сельскохозяйственной техникой. Диаметр кургана - 42,0 м, высота - 1,8 м. Насыпь кургана сооружалась в два этапа [Лукпанова 2020: 111], под насыпью кургана был выявлен бревенчатый настил, поверх которого уложены блоки - «вальки» из верхнего гумусового горизонта. Впоследствии, в традициях погребального обряда VI-V вв. до н.э., конструкция была сожжена, бревна обгорели, «вальки» прокали-

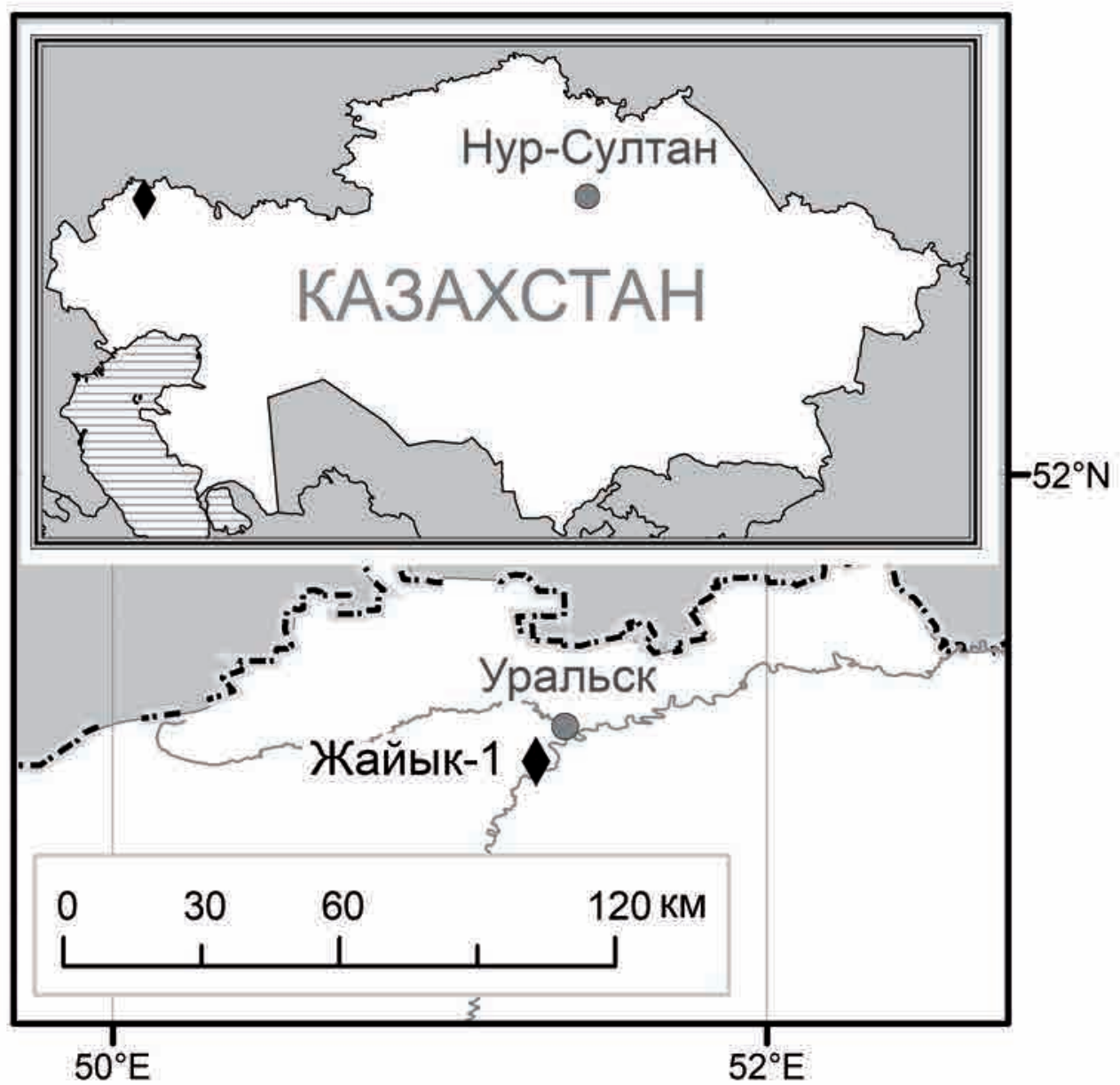

Рис. 1. Расположение могильника Жайык-1, курган № 1. Карту подготовил М.А. Антонов 1-сур. Жайық 1 қорымының орналасуы, № 1 оба. Картаны дайындаған М.А. Антонов Fig. 1. Location of the burial ground Zhaiyk-1, mound no. 1. Map prepared by M. Antonov 
лись, их размер составлял примерно $30 \times 20 \times 15$ см. По периферии внутренняя насыпь кургана окружена кольцевым рвом с южным входом. Глубина рва варьировалась от 0,50 до 2,5 м, ширина рва от 0,5 до 1,5 м. В заполнении кольцевого рва на разных глубинах обнаружены камни (песчаник?), мел, кости животных, фрагменты керамики, фрагменты жертвенников.

Период раннего сооружения кургана относится к V-IV вв. до н.э. Курган неоднократно досыпался и дополнялся более поздними впускными захоронениями.

В кургане было выявлено 14 погребений, 15 индивидов, из них два из центрального погребения, остальные были погребены в ямах, расположенных полукольцом вокруг центральной ямы, основная их часть ориентирова- на головой на Ю, Ю3, ЮВ (рис. 2). С западной и восточной сторон центральной ямы были выявлены по одному взрослому захоронению погребенных лицом вниз, «на животе» - № 7 и 11, по одному погребению детей-подростков - № 8, 12. В северной периферии кургана зафиксировано три погребения, одно во рву - обезглавленный скелет мужчины (№ 13), голова его покоилась возле кисти правой руки, в ребрах был найден железный наконечник стрелы. Второй на краю рва - № 14, могила разграблена, остался один череп. Третья могила на уровне древнего горизонта, на поверхности рва - № 10. Все три погребения, так или иначе, связаны со рвом, погребенные головой ориентированы на восток с некоторым отклонением на ЮВ. Формы могильных ям в плане

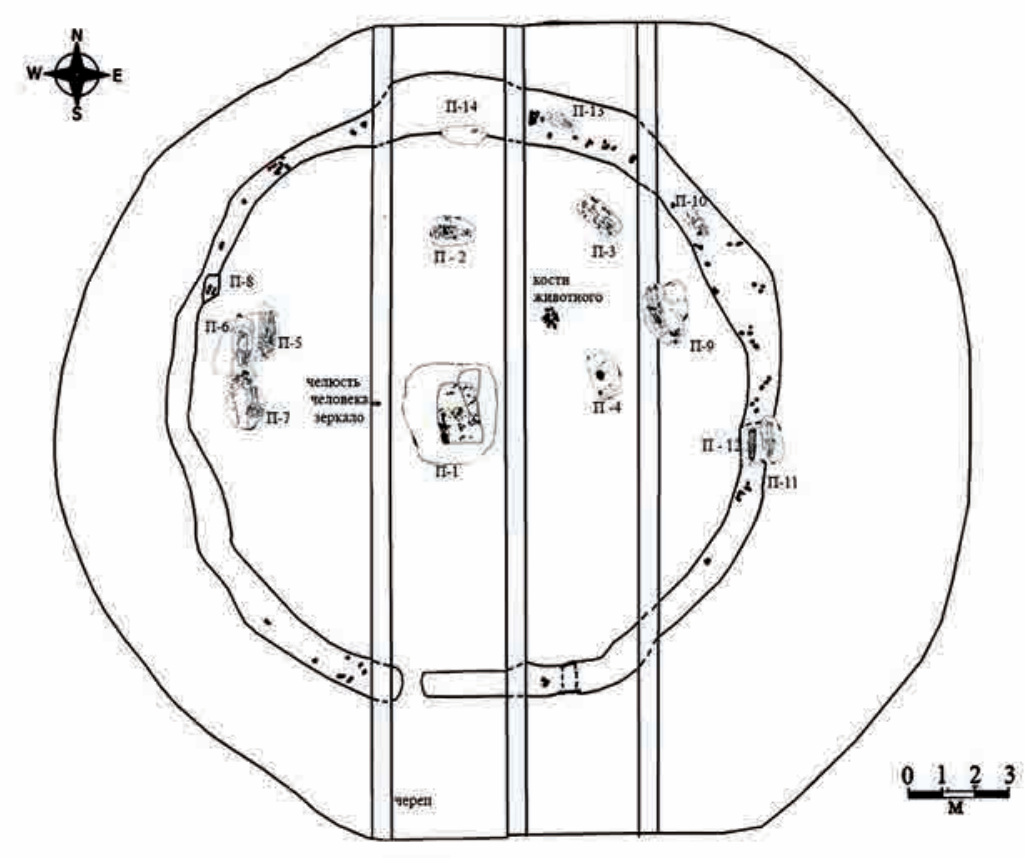

Рис. 2. Жайык-1, курган № 1. План кургана с погребениями 2-сур. Жайық-1, № 1-оба. Обаның жерлеу орнымен сызбасы Fig. 2. Zhaiyk-1, mound no. 1. Burial mound plan 
Лукпанова Я.А. Иерархия общества раннего железного века Западного Казахстана ...

прямоугольные, подбойные, с заплечиками. Пять погребений - № 1, 5, 6, 7,8 , по набору вещей в могилах были атрибутированы как женские, четыре из них сосредоточены в западной части кургана. Исключение составляет погребение № 4, оно расположено с восточной стороны центральной ямы, здесь найдены три стеклянные бусины, разрозненные кости человека. Череп и тазовые кости отсутствуют, что затрудняет определить гендерную принадлежность погребенного, поэтому по наличию бусин мы отнесли его к женскому погребению. Семь погребений - № 2, 3, 9, 11, 12, 13, 14 были обнаружены с северной, восточной, северо-восточной сторон центральной ямы, по так называемому «мужскому» набору вещей в погребениях - определены как мужские. Анализ женских погребений был опубликован ранее [Лукпанова 2020]. В данной статье предлагается анализ мужских захоронений.

Погребение № 2 было выявлено к северу от центральной ямы, могильное пятно длинными сторонами ориентировано по оси 3-В, глубина ямы от уровня материка составила $0,15 \mathrm{M}$, дно ямы не ровное, с восточной и западной сторон фиксируется небольшой подъем, глубина соответственно уменьшается до 0,5 см. В яме обнаружен скелет взрослого человека, предположительно мужчины (рис. 3. 1), головой ориентированного на запад с легким отклонением на север. Череп разбит, кости плохой сохранности, голова находится на левом плече, руки вытянуты вдоль скелета, кисть левой руки покоится на бедренной кости. Ноги вытянуты, берцовые кости раздроблены. Отсутствуют кости нижних конечностей, часть берцовой кости, плюсны, предплюсны. Скелет покрыт органикой черного цвета. С левой стороны, на уровне средней части берцовой кости, выявлено два бронзовых трехлопастных наконечника стрелы без выделенной втулки (рис. 3, 2). С левой стороны погребенного у северной стенки ямы на уровне локтевых костей найдены ребро, лопатка, передняя конечность барана.

Погребение № 3. Яма овальной формы, расположена в 8,5 м северовосточнее центрального погребения, между центральной и восточной бровками. Длинными сторонами яма ориентирована по оси ЮВ-С3. Длина ямы - 2,20 м, глубина ямы от уровня древней поверхности - 1,0 м. Стенки ямы прямые, обложены корой, с СВ и Ю3 сторон ямы на уровне -0,45 м были обнаружены уступы - заплечики шириной 0,20 м. На уступах обнаружены фрагменты дерева, вероятно, остатки перекрытия погребения (рис. 4).

Заполнение ямы однородное, темно-серого цвета с фрагментами дерева. В заполнении встречаются кости зверей (барсук? лиса?), в восточном, западном, южном углах ямы на уровне уступов были обнаружены норы зверей. На дне ямы на органической подстилке выявлено погребение взрослого человека, предположительно мужчины. Скелет находился в вытянутом положении на спине, головой был ориентирован на ЮВ. Руки сложены вдоль скелета, череп был сдвинут животными и покоился в грудной части на ребрах погребенного. В западном углу ямы лежали кости барана, среди которых был найден черешковый нож (рис. 5, 1). Возле левой ноги в районе бедренной кости обнаружены 11 наконечников стрел четырёх типов с утяжелителями древ- 

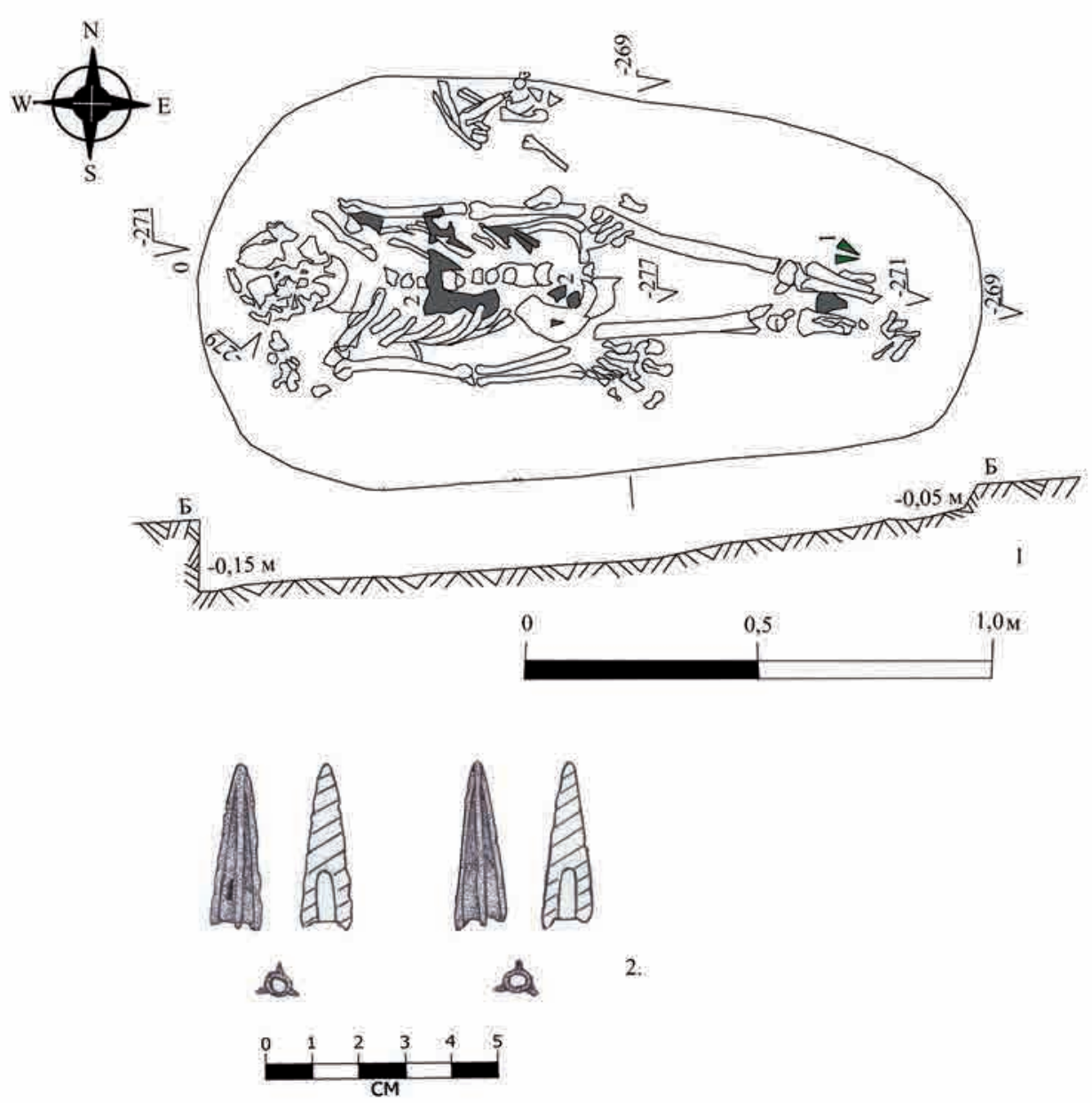

Рис. 3. Жайык-1, курган № 1: 1 - план погребения № 2; 2 - наконечники стрел 3-сур. Жайық-1, № 1-оба: 1 - № 2 жерлеу орны сызбасы; 2 - садақ жебелері

Fig. 3. Zhaiyk-1, mound no. 1: 1 - burial no. 2 plan; 2 - arrowheads

ков (рис. 5, 2). Первый тип: четыре бронзовых втульчатых наконечника с треугольной трехлопастной головкой, лопасти срезаны под прямым углом к втулке; второй тип: два трёхлопастных бронзовых наконечника стрел с внутренней втулкой со средней треугольной головкой; третий тип: два трёхлопастных бронзовых наконечника стрел с внутренней втулкой с длинной треугольной головкой, лопасти срезаны под косым углом к втулке; четвёр- тый тип: три железных трехлопастных наконечника стрел. Возле кисти левой руки были найдены фрагменты железного предмета, возможно, это деталь узды (рис. 5, 3).

Погребение № 9 зафиксировано в восточной части кургана, основная часть ямы оказалась под бровкой, в 9,0 м северо-восточнее центрального репера, в 4,5 м к северу от «R» по восточной бровке. Яма длинными сторонами ориентирована по оси С-Ю с не- 


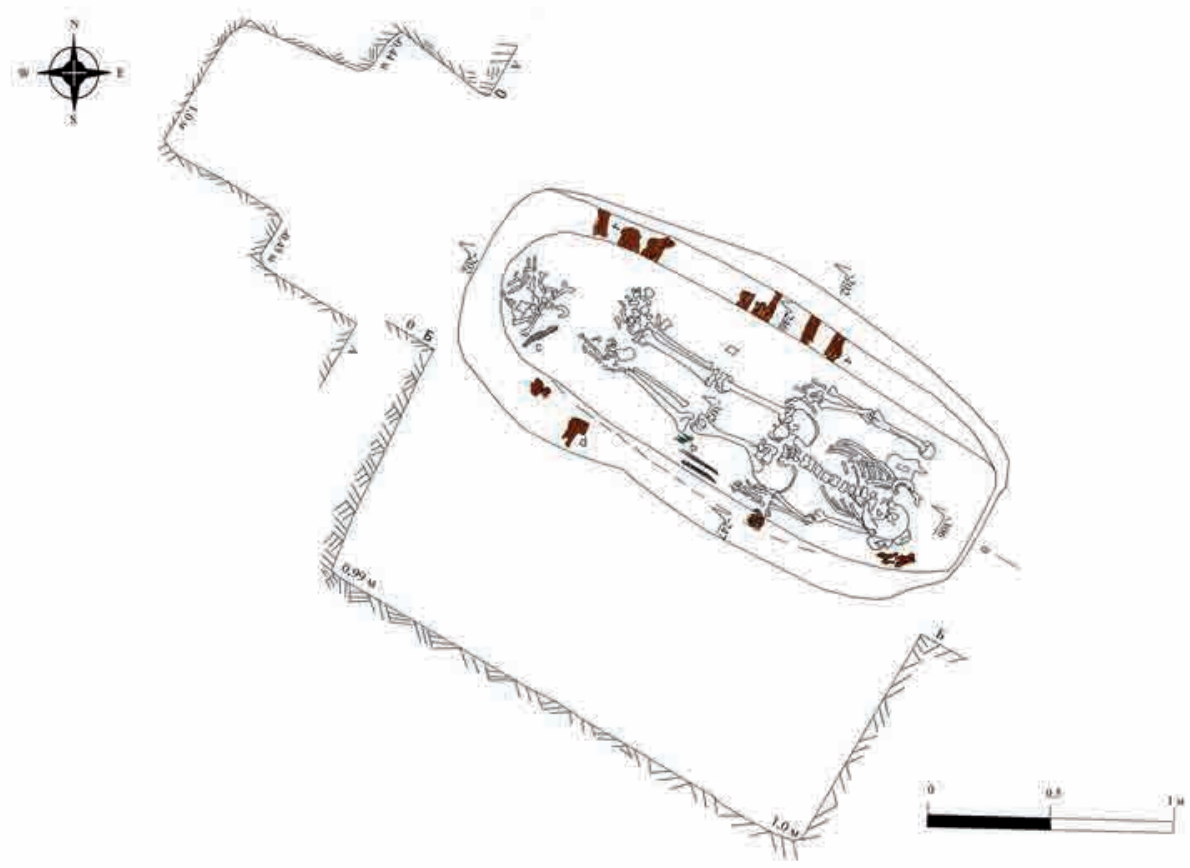

Рис. 4. Жайык-1, курган № 1: 1 - план погребения № 3 (а - фррагменты предмета из железа; $b$ - наконечники стрел; $c$ - черешковый нож; $d$ - фрагменты сохранившегося дерева)

4-сур. Жайық-1, № 1-оба. 1 - № 3 жерлеу орны сызбасы (а - темірден жасалған заттың бөлшегі; $b$ - садақ жебелері; $c$ - шегелі пышақ; $d$ - сақталған ағаш бөлшегі)

Fig. 4. Zhaiyk-1, mound no. 1: 1 - burial no. 3 plan ( $a$ - fragments of an object made of iron; $b$ - arrowheads; $c$ - tanged knife; $d$ - fragments of preserved tree)

которым отклонением на ЮВ-С3. Размеры могильного пятна 2,40×10,5 м. Заполнение представляло собой плотный гумус светло-коричневого цвета.

С восточной стороны ямы зафиксирована ступенька размерами $8,0 \times 3,75$ м на глубине $-0,73$ м от древней поверхности. Дно ямы зафиксировано на глубине -3,50 м от «R».

На дне ямы, на черном органическом тлене, обнаружено погребение мужчины, головой ориентированного на ЮВ с некоторым отклонением на юг (рис. 6). Руки вытянуты, правая и левая кисти находятся ладонью вниз, ноги вытянуты, левая нога вывернута влево. Голова повернута вправо. На правой бедренной кости и на левой кисти лежит короткий меч с навершием в виде двух загнутых когтевидных окончаний и бабочковидным перекрестьем (рис. 7, 1).

В ЮВ углу ямы у изголовья погребенного выявлена тризна в виде лопатки и левой конечности барана, рядом положен колчан (рис. 7, 2), на кожухе которого сохранились фрагменты шкуры животного. В колчане находилсь: наконечники стрел (рис. 7, 3), проколка, шило и копьевидный наконечник (рис. 7, 4). Рядом с колчаном найден колчанный крючок (рис. 7, 5). Южнее этих предметов чуть выше черепа обнаружен плоскодонный лепной горшок с коротким горлышком, плоским дном, шаровидным туловом (рис. 7, 6). 


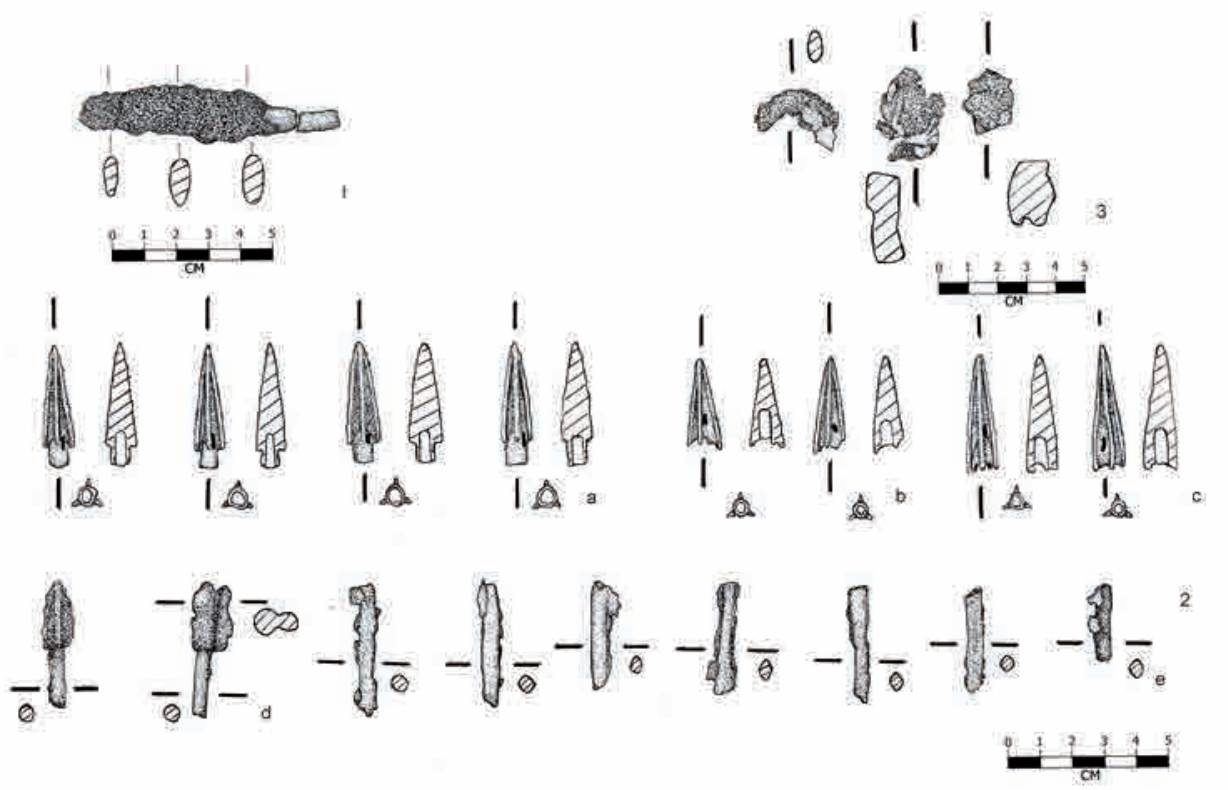

Рис. 5. Жайык-1, курган № 1, погребение № 3: 1 - черешковый нож; 2 - набор стрел ( $a$ - втульчатые, трехлопастные наконечники стрел; $b$ - трехлопастные наконечники стрел со средней треугольной головкой, внутренней втулкой; $c$ - трехлопастные наконечники стрел с длинной треугольной головкой, внутренней втулкой; $d$ - железные наконечники стрел; e - железные утяжелители древков); 3 - фррагменты предметов из железа

5-сур. Жайық-1, № 1-оба, жерлеу орны № 3: 1 - шегелі пышақ; 2 - садақ жебелері жиынтығы (a - ұңғылы, үш қанатты садақ жебелері; $b$ - орташа үшбұрышты басты, ішкі ұңғылы, үш қанатты садақ жебелері; c - ұзын үшбұрышты басымен үш қанатты садақ жебелері, ішкі ұңғымен; $d$ - темір жебелер; e - сабына салмақ беретін темір құрал); 3 - темірден жасалған заттың бөлшегі

Fig. 5. Zhaiyk-1, mound no. 1, burial no. 3: 1 - tanged knife; 2 - set of arrows (a-socketed, three-blade arrowheads; $b$ - three-blade arrowheads with middle triangular head, inner socket; $c$ - three-blade arrowheads with long triangular head, inner socket; $d$ - iron arrowheads; e - iron shaft weights); 3 - fragments of iron objects

Погребение № 10 выявлено в 10,5 м к северу и в 9,5 м к востоку от «R» на уровне древнего горизонта на поверхности рва. Предположительно оно принадлежало мужчине, головой ориентированного на юго-восток, руки и ноги его вытянуты, голова повернута на север. Кости плохой сохранности. С левой стороны черепа выявлен камень треугольной формы, с левой стороны - на уровне тазовых костей - два фрагмента керамики (рис. 8, 1).

Погребение № 11 находилось в восточной периферии кургана за границами кольцевого рва, в 12,5 м к востоку от «R». Яма округлой формы, длинными сторонами ориентирована по оси С-Ю. Западная стенка ямы заходит в стенку рва. Длина ямы 2,17 м, ширина $-1,25$ м. Заполнение ямы неоднородное, оно представляло собой мягкий гумус черного цвета, ниже в заполнении встречались камни, мел, фрагменты дерева, перемес с материковой супесью. Дно ямы было зафиксировано на уровне -3,54 от «R». Погребение принадлежит взрослому человеку, он погребен лицом вниз, головой ориентирован на юг, череп слег- 
Лукианова Я.А. Иерархия общества раннего железного века Западного Казахстана ...

ка повернут на запад, руки вытянуты вдоль туловища, ноги вытянуты, пятки соединены. Вдоль западной стенки находятся кости барана с лопаткой. На дне ямы простелена органика, вероятно дерево, были зафиксированы фрагменты дерева и кости. На костях были обнаружены фрагменты коры. Инвентарь отсутствует (рис. 8, 2).
Погребение № 12. Могильная яма расположена во рву, впускное, примыкает восточной стенкой к яме погребения № 11 (рис. 8, 3). Размеры ямы $1,75 \times 0,85$ м. Дно ямы было зафиксировано на уровне $-2,74$ м от «R». Яма вытянута длинными сторонами по оси С-Ю. Заполнение ямычерный гумус, в нем встречались ку-

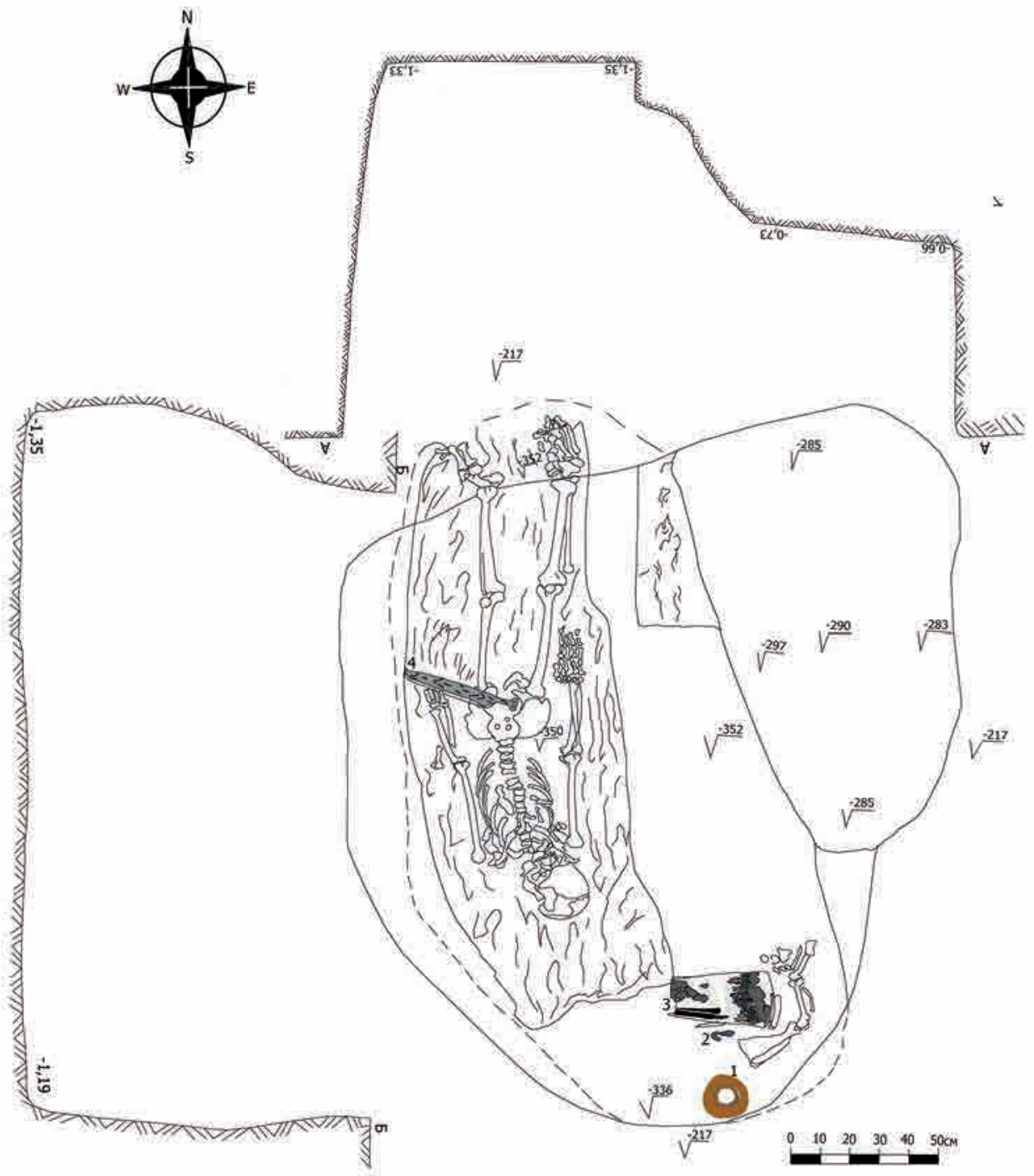

Рис. 6. Жайык-1, курган № 1, погребение № 9 6-сур. Жайық-1, № 1-оба, № 9 жерлеу орны

Fig. 6. Zhaiyk-1, mound no. 1, burial no. 9 


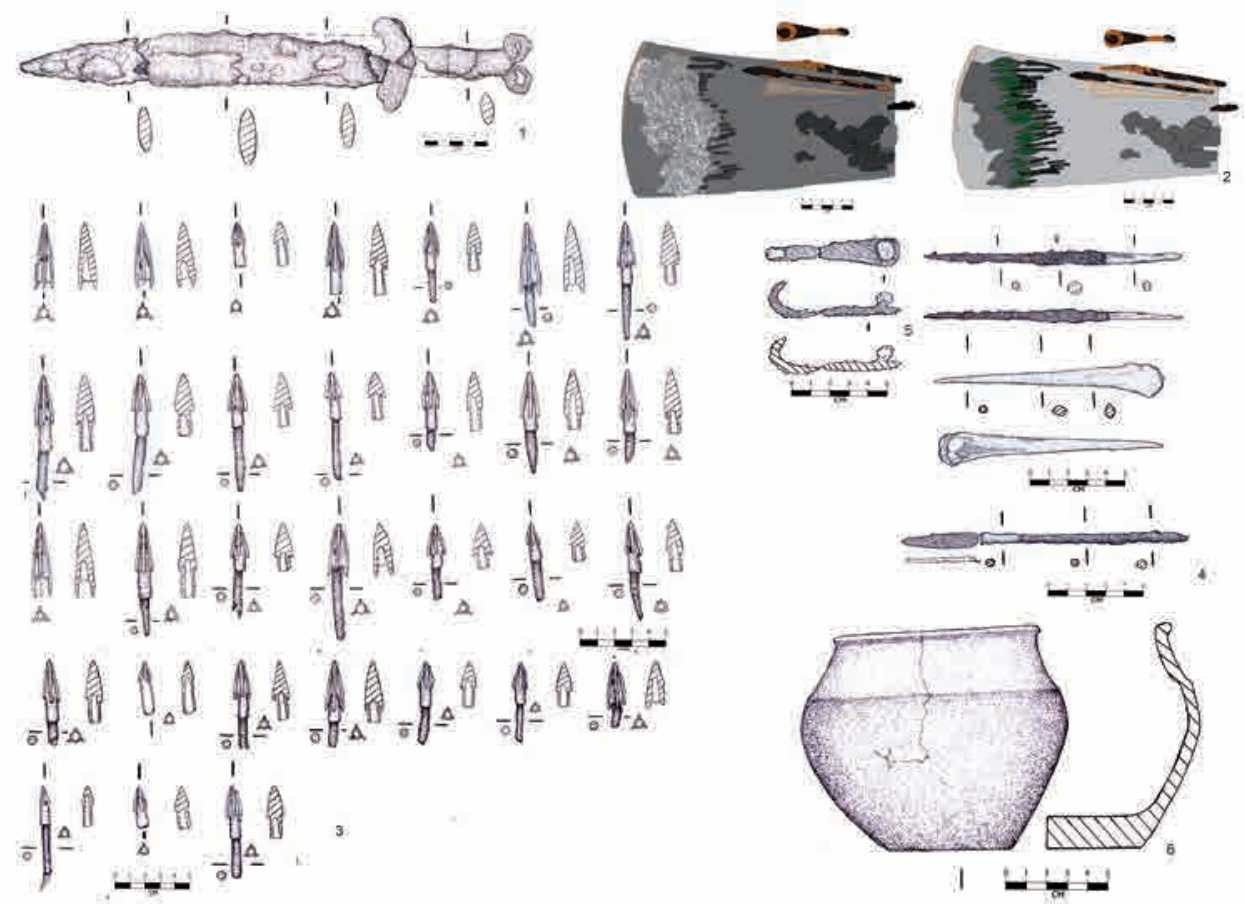

Рис. 7. Жайык-1, курган № 1, погребение № 9: 1 - меч; 2 - колчан;

3 - наконечники стрел; 4 - проколка, шило, копьевидный наконечник; 5 - колчанный крючок; 6 - лепной горшок

7-сур. Жайық-1, № 1-оба, № 9 жерлеу орны: 1 - қылыш; 2 - қорамсақ; 3 - садақ жебелері; 4 - тескіш, біз, найза тәрізді жебе; 5 - қорамсақ ілгегі; 6 - жапсырмалы ыдыс

Fig. 7. Zhaiyk-1, mound no. 1, burial no. 9: 1 - sword; 2 - quiver; 3 - arrowheads; 4 - piercer, awl, spear-shaped tip; 5 - quiver hook; 6 - molded pot

ски мела, камни. В юго-восточном углу ямы на поверхности был выявлен лепной горшок с шаровидным туловом (рис. 8, 6) На дне ямы была обнаружена деревянная колода, вырезанная из ствола дерева. Длина её 1,40 м, ширина 0,35 м. Внутри колоды выявлен скелет ребенка, головой ориентированного на юг, руки вытянуты вдоль скелета, ноги согнуты в коленях, в позе всадника. Между ногами выявлены кости овцы: тазовая кость, конечности. Вдоль бедренной кости правой ноги обнаружен железный обоюдоострый черешковый нож (рис. 8, 5), под правым запястьем руки выявлена округлая бусина коричневого цвета, центральная часть бусины выделена зоной из двух полосок белого цвета, по центру которой проходит белая волнистая линия (рис. 8, 4).

Погребение № 13 обнаружено на дне рва в 16,0 м к северу и в 1,8 м к востоку от условного центра в северной периферии кургана, между центральной и восточной бровками. Погребение принадлежит предположительно мужчине, он погребен на тонкой органике коричневого цвета, скелет его вытянут по оси 3-В, ноги прямые, вытянуты параллельно друг другу, руки вытянуты вдоль туловища, череп погребенного перевернут, покоился на кисти правой руки, нижняя челюсть лежит близ черепа с шейными позвонками (рис. 9, 1). Инвентарь 

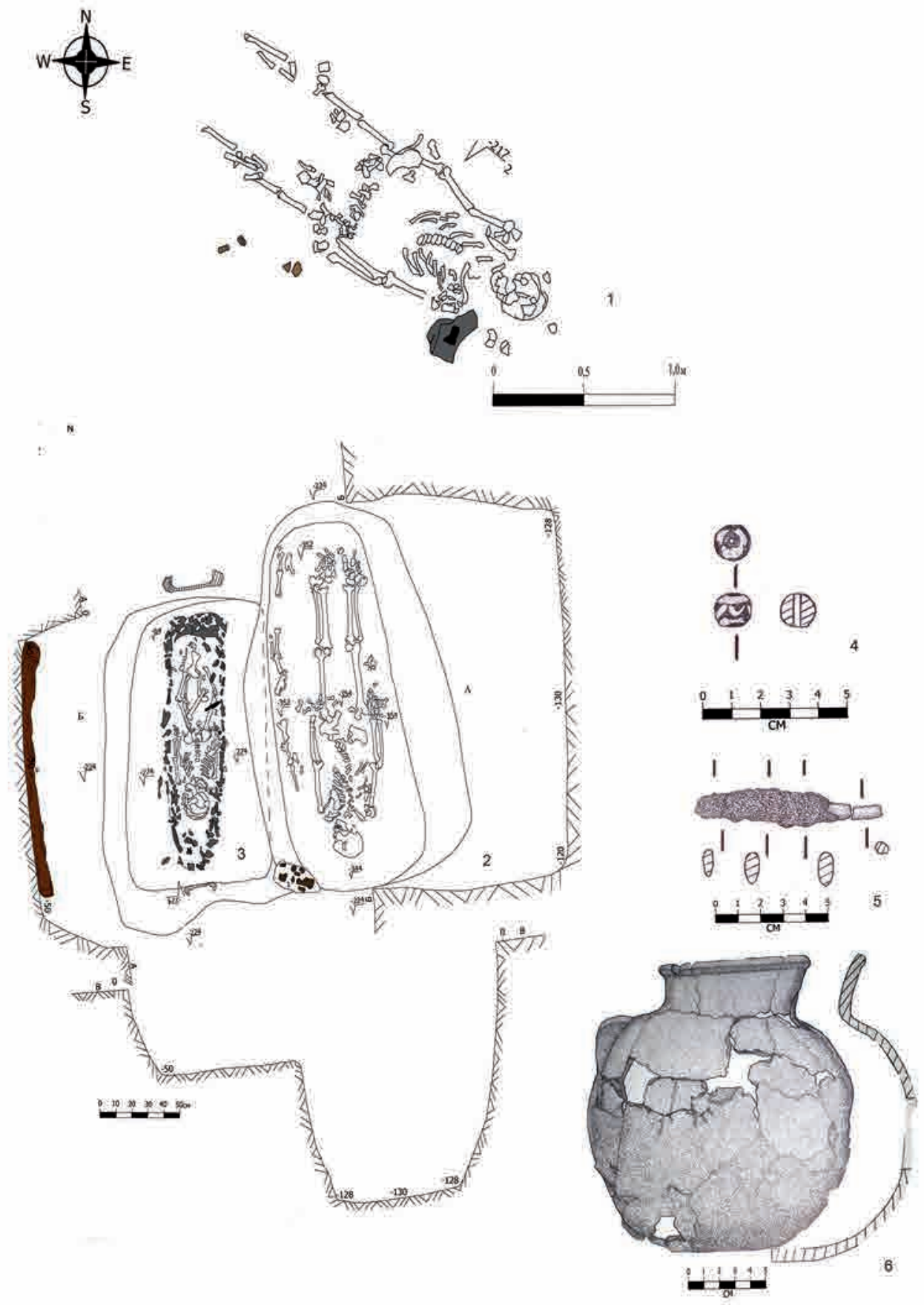

Рис. 8. Жайык-1, курган № 1: 1 - план погребения № 10; 2 - план погребения № 11; 3 - план погребения № 12; 4 - бусина; 5 - черешковый нож; 6 - лепной горшок. 4-6 - погребение № 12

8-сур. Жайық-1, № 1-оба: 1 - № 10 жерлеу орны; 2 - № 11 жерлеу орны жоспары; 3 - № 12 жерлеу орны жоспары; 4 - моншақ; 5 - шегелі пышақ; 6 - жапсырмалы ыдыс. 4-6 - № 12 жерлеу орны

Fig. 8. Zhaiyk-1, mound no. 1: 1 - burial no. 10 plan; 2 - burial no. 11 plan; 3 - burial no. 12 plan; 4 - bead; 5 - petiole knife; 6 - molded pot. 4-6-burial no. 12 
не обнаружен, в заполнении рва были найдены кости лошади, камни, мел. В ребрах обнаружен железный черешковый наконечник стрелы (рис. 9, 2).

Погребение № 14. Могильная яма расположена в 5,0 м к северу и в 1,5 м к западу от «R», находится на одной линии с центральным погребением и погребением № 2. Ее размеры $2,0 \times 0,85$ м, вытянута по оси 3-В. Дно ямы было зафиксировано на уровне $-2,53$ м от «R», её северная сторона примыкает к краю рва. В яме обнаружен череп взрослого человека плохой сохранности, лежащий на челюсти овцы, рядом находился фрагмент жертвенника и черешковый нож. Вероятно, погребение разграблено.

В заполнении кольцевого рва на разных глубинах были зафиксированы камни, мел кости животных, фрагменты керамики и жертвенников.

Анализ и обсуждение материала

Погребение № 2 по наличию наконечников стрел, соответствующих по классификации К.Ф. Смирнова, В.Г. Петренко отделу III, типу 19, датируются V-IV вв. до н.э. [Смирнов, Петренко 1963: табл. 13, 382, 383], наличие тризны в виде передней части барана и совершение погребения на уровне древнего горизонта также позволяют отнести погребение к указанной дате.

Погребение № 3 было совершено в яме с заплечиками. Как отмечает М.Г. Мошкова, подобные ямы как устойчивый тип погребального обряда появляются на рубеже IV-III вв. до н.э. [Мошкова 1963: 20]. В эти же даты вписываются наконечники стрел из колчана, найденного с левой стороны воина, что само по себе немаловажно, так как в IV-III вв. до н.э. подобное положение как колчана, так и набора стрел, по мнению В.К. Федорова, становится уже почти незыблемым [Федоров 2013: 44]

К ранней группе из представленных мужских комплексов относится захоронение воина из погребения № 9, датируемого IV в. до н.э. Эту дату подтверждают предметы, найденные в погребении. Колчан обнаружен с правой стороны погребенного, у изголовья, сохранился фрагмент корпуса горита из кожи и шкуры животного. Колчан состоял из двух отделов, в основном отделе был найден 31 бронзовый трехлопастной наконечник стрелы, в боковом отделе - проколка из кости, копьевидный железный наконечник, шило.

Проколки с широким верхним необработанным краем и сильно заостренным нижним концом изготавливались из путовой кости лошади [Скрипкин 1990: 100], они получили свое распространение в раннесарматский период, но первое их появление зафиксировано уже в «савроматских» комплексах [Мошкова 1963: 39; Скрипкин 1990: 100; Клепиков 2002: 74].

Шило представляло собой круглый в сечении железный стержень, заостренный к рабочему концу, на противоположном конце сохранились следы деревянной рукоятки. [Мошкова 1963: 35]. Копьевидный наконечник представлял собой железный стержень, округлый в сечении, заканчивающийся лавролистной пластиной. Они встречаются редко в составе наконечников стрел, скорее всего, предназначались для хозяйственно-бытовых нужд, например, ремонта. Небольшие инструменты использовались вплоть до ру- 
Лукианова Я.А. Иерархия общества раннего железного века Западного Казахстана ...

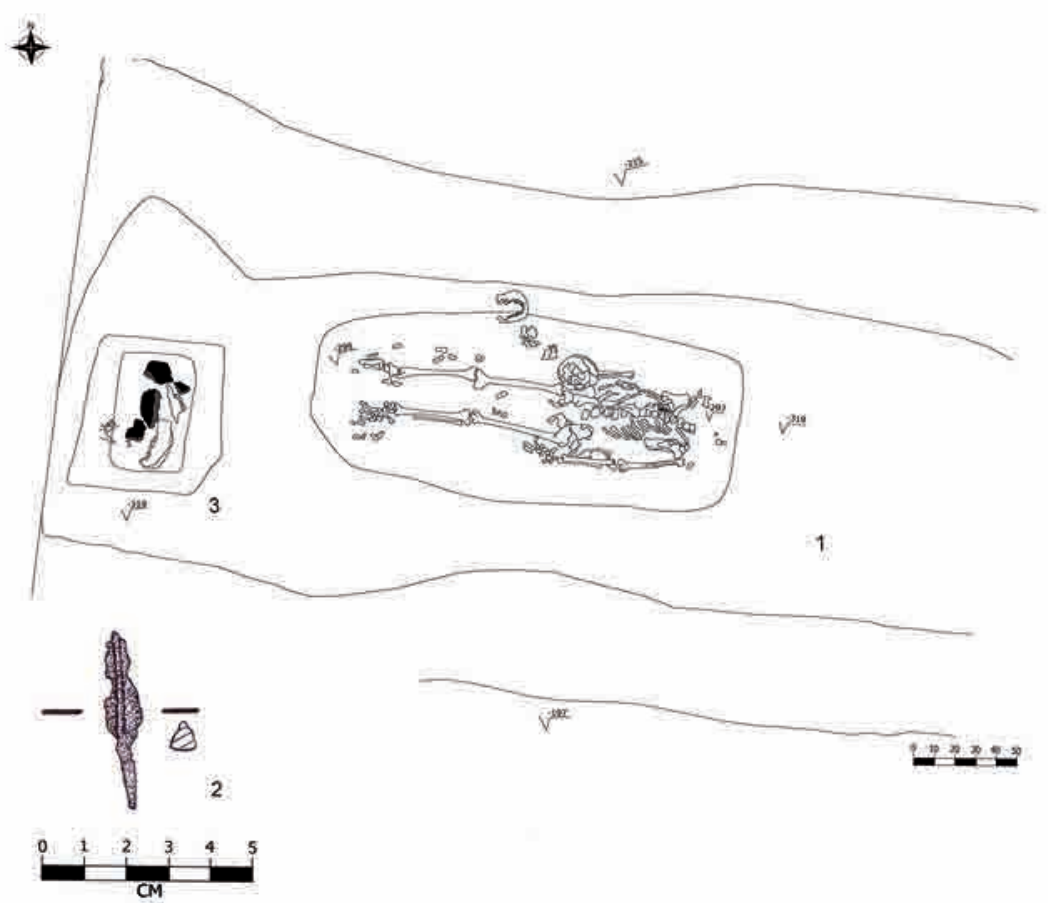

Рис. 9. Жайык-1, курган № 1: 1 - план погребения № 13; 2 - железный наконечник стрелы; 3 - камни в заполнении ямы

9-сур. Жайық-1, № 1-оба: 1 - № 13 жерлеу орны жоспары; 2 - темір садақ жебесі; 3 - жерлеу шұңқырындағы тастар

Fig. 9. Zhaiyk-1, mound no. 1: 1 - burial no. 13 plan; 2 - iron arrowhead; 3 - pit filling stones

бежа эр и существенно не менялись, в качестве маркеров того или иного периода использоваться не могут.

Колчанный крючок, найденный рядом с горитом, изготовлен из железной пластины и является конструктивным элементом колчанной портупеи. Подобные крючки - изготовленные из прямой пластины, сужающейся к загнутому в крючок концу, на внутренней стороне которых имеется петля, расположенная перпендикулярно продольной оси пластины, датируются V-IV вв. до н.э. [Смирнов, Петренко 1963: табл. 15, рис. 28], IV в. до н.э. [Мошкова 1963: табл. 15, рис. 28 ].

Лепной яйцевидный, плоскодонный горшок из погребения № 9, с ровным невысоким горлом, отделенным от тулова каннелюром, является «характерной особенностью прохо- ровской керамики» [Мошкова 1963: 25; табл. 5, 8].

Вещевой материал в погребении № 10 представлен двумя маленькими фрагментами лепного горшка и камнем, найденным у изголовья. Камни и гальки встречаются в раннесарматских погребениях, возможно, их помещали в могилу как символ того или иного предмета, либо они относились к категории ритуальных атрибутов. В.М. Клепиков выделял 19 случаев выявления необработанных камней и галек в погребениях IV-III вв. до н.э. [Клепиков 2002: 76]. Такие предметы не служат хроноиндикаторами, а немногочисленность вещей в погребении не позволяет точно датировать данное погребение.

Захороненный в погребении № 11 покоился лицом вниз, на животе. 
Ранее, в контексте анализа женских погребений, изученных в данном кургане, описывалась аналогичная ситуация: погребение принадлежало женщине, захороненной также лицом вниз [Лукпанова 2020]. В отличие от женского погребения, данное захоронение было безынвентарное, не считая камней в заполнении. Заупокойная пища представлена передней конечностью с лопаткой барана, что является важной особенностью раннесарматского погребального обряда [Мошкова 1963: 24]. Учитывая особенности захоронения, конструкцию погребальной ямы, погребение возможно датировать IVIII в. до н.э. Подобные захоронения встречаются редко в раннем железном веке, М.А. Балабанова выделяет $5 \%$ из общего количества [Балабанова 2011: 23]. Вопрос о символике подобных захоронений остается открытым и дискуссионным.

Погребение № 12 также относится к категории редких захоронений, так как оно выполнено в деревянной колоде, выдолбленной из ствола дерева. Подобные захоронения, называемые гробами-колодами, у сарматов появляются на рубеже IV-III вв. до н.э. и встречаются не часто [Мошкова 1963: 38].

Вещевой материал рассматриваемого захоронения представлен лепным сосудом, бусиной и черешковым ножом. Лепной круглодонный сосуд с шаровидным туловом из-за низкой температуры обжига имел плохую сохранность, глина рассыпается, расслаивается. На плече сосуда находилась ручка-«ушко», подобные горшки датируются III в. до н.э. Сосуд был оставлен в яме в процессе завершения погребального обряда и обнаружен был на поверхности заполнения ямы.
Бусина округлая, с орнаментом в виде поперечных прямых волнистых линий: у данного вида процент от общего количества бус небольшой по сравнению с гешировыми и с бусинами с внутренней позолотой. Несмотря на то, что бусы сложно использовать в культурно-хронологической реконструкции, они не могут служить абсолютным хроноиндикатором, но на основе сопоставления с типами прохоровских бус, предложенных М.Г. Мошковой, можно высказать предположение, что похожие бусы встречаются в IV-II вв. до н.э.

Черешковый нож также не является маркером для датировки данного погребения, так как черешковые ножи встречаются очень широко [Клепиков 2002: 72]. Погребение № 12 датируется III в. до н.э.

Погребение № 13 принадлежит обезглавленному мужчине, погребенному во рву. Инвентарь отсутствовал, за исключением железного черешкового наконечника стрелы. Вероятно, мужчина был сначала убит, а потом обезглавлен. Наконечник был найден среди ребер. Железные черешковые наконечники стрел с треугольным силуэтом головки появляются на рубеже IV-III вв. до н.э. [Хазанов 1971: 36-37; Клепиков 2002: 46-47]. Данное захоронение датируется предварительно IV-III вв. до н.э.

Погребение № 14 по наличию имеющегося инвентаря сложно датировать.

Таким образом, в кургане было выявлено восемь мужских захоронений, из них с инвентарем семь (№ 2, $3,9,10,12,13,14)$, безынвентарных одно (№ 11). С заупокойной пищей шесть погребений (№ 2, 3, 9, 11, 14), из них только одно с задней конечно- 
Лукпанова Я.А. Иерархия общества раннего железного века Западного Казахстана ...

стью и тазовой костью барана. Два захоронения без напутственной пищи (№ 10, 13). Пять захоронений так или иначе относятся ко рву, два из них совершены на дне рва (№ 12, 13), одно захоронение - на поверхности рва (№ 10), два погребения - на границе со рвом (№ 11, 14). Два захоронения по имеющемуся вещевому набору и типам ям датируются более ранним периодом - V-IV вв. до н.э., остальные погребения датируются IV-III вв. до н.э.

Вещевой комплекс в погребениях являлся маркером социального положения погребенного, при этом социальный и военный статус были взаимосвязны [Клепиков 2002: 109]. Погребальная обрядность выполняла по отношению к социальной структуре определенный ряд функций, что включало в себя символизацию принципов и статуса организации общества, норм поведения, разделение социальных ролей и статусов в обществе [Мышкин 1999: 284]. Поэтому строительство сложных погребальных ям, наличие в захоронениях определенного набора вещей, взаимосвязных между собой, выступающих элементами погребального обряда, и определяло место умершего в социальной структуре сармат.

Из рассмотренных восьми погребений к воинской элите мы можем отнести погребение № 9. Оно является наиболее представительным, с оружием в виде меча и колчана со стрелами, лепным сосудом, с заупокойной пищей в виде костей барана. Погребения № 2 и 3 принадлежат воинам по статусу ниже, материал представлен набором с незначительным количеством стрел, другие виды оружия и вещей отсутствуют.
Погребение № 12, принадлежащее мальчику-подростку, лежащему в колоде в позе всадника, также можно рассматривать как захоронение представителя элиты. Для представителей знати подобные «специфические позы были характерны» [Очир-Горяева 2019: 817], возможно, нож у правой руки подростка символизировал собой наличие акинака в погребальном обряде.

Погребения № 10, 14 возможно рассматривать как погребения рядовых представителей кочевого общества. Наличие минимального количества вещей в погребениях, отсутствие заупокойной пищи, как в погребении № 10, отсутствие погребальных ям позволяет сделать вывод о наличии захоронений людей, занимающих более низкую социальную ступень в кочевом обществе.

Обезглавленный скелет из рва, в погребении которого отсутствуют тризна и вещи, дает основание высказать предположение о его социальном статусе, возможно, он пленник или же раб. Отсутствие в могиле костей жертвенных животных может подчеркивать более низкий социальный статус у погребенного [Берлизов 2020: 42].

Символика погребений, совершенных на животе, может объясняться также социальными различиями, возможно специфическими обстоятельствами смерти [Смирнов 1989: 171]. В данном кургане выявлено два таких погребения, принадлежащих мужчине и женщине, расположенных симметрично в восточной и западной частях кургана, головой ориентированы на юг. В обоих погребениях зафиксированы кости барана. Захоронения совершены в ямах разных форм, женщина погребена в яме с подбоем, 
мужчина - в яме с прямыми стенками. В женском погребении найдены пряслице и лепной горшок. Безусловно, их похоронили с соблюдением какого-то определенного ритуала, и они занимали определенный статус в кочевом обществе. Если сравнивать эти погребения с погребениями № 10 и 13, то можно отметить, что статус у погребенных ничком по отношению к ним был выше.

\section{Заключение}

Таким образом, курган № 1 могильника Жайык-1 представлял собой курган-кладбище, в котором погребения были расположены по определенному принципу, в данном случае полукольцом. Женские погребения были расположены в западной части кургана, все мужские - в восточной. Погребённые покоились в различных видах могильных ям, встречаются погребения, которые были выполнены во рву, на уровне древнего горизонта; в прямоугольных ямах, в ямах с заплечиками, в ямах с подбоем; вытянуто на спине, головой преимущественно к югу, с некоторым отклонением на ЮB, Ю3.

Все женские погребения в кургане - с содержательным сопроводительным вещевым материалом, что нельзя сказать о мужских захоронениях, в них, за исключением погребений № 2, 3, 9, 13, если и есть вещевой материал, то он очень бедный, чаще всего фрагментированный. Важно отметить, что детские захоронения выполнены во рву и на краю рва. Обезглавленный скелет во рву, еще три погребения выполнены на краю рва, возможно, ров играл определенную роль в погребальном обряде. На фоне мужских захоронений, выполненных во рву и на поверхности рва, погребения мужчины и женщины, лежащих на животе, обретают более высокий статус. Два детских захоронения также можно отнести к категории нерядовых, наличие украшений и кувшина в погребении девочки и ножа, бусины в погребении мальчика, покоившегося в колоде, говорит о статусе этих детей, так как детские захоронения чаще всего безынвентарные.

Из восьми мужских захоронений два погребения (№ 2, 9) датируются V-IV вв. до н.э. и IV в. до н.э. Погребение № 3 датируется IV-III вв. до н.э., погребение № 12 датируется III в. до н.э. Эти погребения относятся к представителям более высокой страты кочевого общества, следующую ступень занимает погребение № 11, совершенное в могильной яме прямоугольной формы, с сопроводительной напутственной пищей. Несмотря на то, что интерпретация подобных погребений еще остается дискуссионной, возможно предположить, что оно связано с погребением № 12 . Не совсем ясна ситуация с погребением № 14, здесь возможно мы сталкиваемся с обрядом жертвоприношения, так как яма стерильная, в заполнении не встречались разрозненные кости человека и материал представлен черепом человека, челюстью барана, ножом и фрагментом жертвенника, сложенного в восточной части ямы.

Подводя итоги сказанному, важно отметить, что в рамках исследования одного кургана был получен материал, касающийся целого блока вопросов по археологии ранних кочевников региона. На основе анализа особенностей возведения подкурганной конструкции, системы захоронений, организации погребального 
Лукпанова Я.А. Иерархия общества раннего железного века Западного Казахстана ...

пространства, характера предметного комплекса обозначены проблемы гендерного обозначения, социальной организации, иерархии общества ранних кочевников в течение трех столетий. Полученные в ходе исследования кургана № 1 данные позволяют высказать предположение о высоком статусе женщин в сарматском обществе. В целом, могильник Жайык-1 показал перспективность дальнейших исследований, в том числе с использованием прикладных дисциплин.

\section{ЛИТЕРАТУРА}

1. Балабанова М.А. Поза погребенных как объект археолого-этнографических исследований (по погребальным комплексам позднесарматского времени) // Погребальный обряд ранних кочевников Евразии. Материалы и исследования по археологии Юга России. Ростов-на-Дону: изд-во ЮНЦ РАН, 2011. Вып. ІІІ. С. 23-39.

2. Берлизов H.Е. Кости жертвенных животных из савроматских погребений как индикатор социального положения погребенного // Ранние кочевники Южного Урала и Нижнего Поволжья. М-лы Круглого стола «Археология ранних кочевников евразийской степи: актуальные проблемы и перспективы их решения»: к юбилею д.И.н. М. Г. Мошковой / Отв. ред. С.В. Сиротин. М.: Институт археологии РАН; МАКС Пресс, 2020. С. 32-43.

3. Клепиков B.M. Сарматы Нижнего Поволжья в IV-III вв. до н.э. Волгоград: изд-во ВолГУ, 2002. $216 \mathrm{c.}$

4. Лукпанова Я. Женские погребения из кургана № 1 могильника Жайык-1 в Западном Казахстане // Теория и практика археологических исследований. 2020. Т. 30, № 2. C. 111-127.

5. Мошкова М.Г. Памятники прохоровской культуры // САИ. Вып. Д1-10. М.: издво АН СССР, 1963. $56 \mathrm{c}$.

6. Мышкин В.Н. К проблеме взаимосвязи социальной структуры и погребальной обрядности в древних обществах // Вопросы археологии Поволжья. 1999. Вып. 1. C. $270-288$.

7. Очир-Горяева М.А. Поза всадника по археологическим и этнографическим данным // Oriental Studies. 2019. 5. C. 812-821. DOI: 10.22162/2619-0990-2019-5812-821.

8. Скрипкин А.С. Азиатская Сарматия. Проблемы хронологии и ее исторический аспект. Саратов: изд-во Сарат. ун-та, 1990. 299 с.

9. Смирнов К.Ф. Савроматская и раннесарматская культуры // Степи европейской части СССР в скифо-сарматское время / Отв. ред. А.И. Мелюкова. М.: Наука, 1989. C. $165-176$.

10. Смирнов К.Ф., Петренко В.Г. Савроматы Поволжья и Южного Приуралья / САИ. Вып. Д1-9. М.: Наука, 1963. 40 с.

11. Федоров В.К. Костяные ложечки в колчанах ранних кочевников // Российская археология. 2013. № 2. С. 44-61.

12. Хазанов А.М. Очерки военного дела сарматов. М.: Наука, 1971. 171 с.

\section{REFERENCES}

1. Balabanova, M. A. 2011. In: Pogrebalnyi obryad rannih kochevnikov Evrazii. Materialy i issledovaniya po arheologii Yuga Rossii (Funeral rite of the early nomads of Eurasia. Materials and research on archeology of the South of Russia), 3, 23-39. Rostov on Don: Yuzhnyi nauchnyi tsentr RAN Publ. (in Russian). 
2. Berlizov, N. E. 2020. In: Sirotin, S. V. (ed.). Rannie kochevniki Yuzhnogo Urala i Nizhnego Povolzhiya (Early nomads of the Southern Urals and the Lower Volga region). Moscow: Institute of Archeology RAS; "MAKS Press" Publ., 32-43 (in Russian).

3. Klepikov, V. M. 2002. Sarmaty Nizhnego Povolzhiya v IV-III vv. do n.e. (Sarmatians of the Lower Volga region in the $4^{\text {th }}-3^{\text {rd }}$ centuries $B C$ ). Volgograd: Volgograd State University Publ. (in Russian).

4. Lukpanova, Ya. A. 2020. In: Theory and practice of archaeological research, 30, no. 2, 111-127 (in Russian).

5. Moshkova, M. G.1963. Pamyatniki prohorovskoy kultury (Monuments of Prokhorov culture). Svod arheologicheskih istochnikov (Collection of archaeological sources), D1-10. Moscow: USSR Academy of sciences Publ. (in Russian).

6. Myshkin, V. N. 1999. In: Archeological issues of the Volga region, 1, 270-288 (in Russian).

7. Ochir-Goryaeva, M. A. 2019. In: Oriental Studies, 5, 812-821. DOI: 10.22162/26190990-2019-5-812-821 (in Russian).

8. Skripkin, A. S. 1990. Aziatskaya Sarmatiya. Problemy hronologii i ee istoricheskiy aspect (Asian Sarmatia. Problems of chronology and its historical aspect). Saratov: Saratov University Publ. (in Russian).

9. Smirnov, K. F. 1989. In: Melyukova, A. I. (ed.). Stepi evropeyskoy chasti SSSR v skifosarmatskoe vremya (The steppes of the European part of the USSR in the Scythian-Sarmatian time). Moscow: "Nauka" Publ., 165-176 (in Russian).

10. Smirnov, K. F., Petrenko, V. G. 1963. Savromaty Povolzhiya i Yuzhnogo Priuraliya (Savromats of the Volga and Southern Urals). Svod arheologicheskih istochnikov (Collection of archaeological sources), D1-9. Moscow: "Nauka" Publ. (in Russian).

11. Fedorov, V. K. 2013. In: Rossiyskaya arheologiya (Russian archaeology), 2, 44-61 (in Russian).

12. Khazanov, A. M. 1971. Ocherki voennogo dela sarmatov (Essays on the military affairs of the Sarmatians). Moscow: "Nauka" (in Russian).

\footnotetext{
Мүдделер қақтығысы туралы ақпаратты ашу. Автор мүдделер қақтығысының жоқтығын мәлімдейді.

/ Раскрытие информации о конфликте интересов. Автор заявляет об отсутствии конфликта интересов.

/ Disclosure of conflict of interest information. The author claims no conflict of interest.

Мақала туралы ақпарат / Информация о статье / Information about the article.

Редакцияға түсті / Поступила в редакцию / Entered the editorial office: 21.10.2021.

Рецензенттер мақұлдаған / Одобрено рецензентами / Approved by reviewers: 30.10.2021.

Жариялауға қабылданды / Принята к публикации / Accepted for publication: 30.10.2021.
} 